\title{
Cattle milk quality in the Semiarid region of Rio Grande do Norte, Brazil
}

\section{Qualidade do leite bovino no Semiárido do Rio Grande do Norte, Brasil}

\author{
Marcone Macêdo Tôrres Angicano ${ }^{1 *}$; Alexandre Paula Braga ${ }^{2}$; \\ Luiz Januário Magalhães Aroeira ${ }^{2}$; Adriano Henrique do Nascimento Rangel ${ }^{3}$; \\ Michelle Santos da Silva ${ }^{4}$
}

\begin{abstract}
The aim of this study was to evaluate the composition and quality of raw milk that was refrigerated in tanks, according to the farm structures, bovine diet, and production levels of the dairy producers that provide milk for the Association of Small-Scale Ranchers of the Angicos Wilderness (ASRAW). Data were collected from 47 dairy farmers from different cities of the state of Rio Grande do Norte who are associated with ASRAW. Twenty-three tanks were sampled throughout the month of June 2013, with two collections per week and five samples per tank, for a total of 920 samples. The properties were characterized according to the type of tank (private or community), the food provided during milk collection (voluminous or voluminous and concentrated), the structure of the dairy producer (family producer or non-family producer), and the amounts of each component. Analyses of fat content, total protein, casein levels, lactose levels, total solids, degreased dry extract (DDE), freezing point, urea levels, somatic cell counts (SCC), and antibiotic residues were performed. Statistical analyses were conducted for each group, and the means were compared by Tukey tests, with a critical significance level of 5\% probability calculated with the PROC GLM procedure of the SAS ${ }^{\circledR}$ program. Most components differed significantly for each parameter. The highest difference was noted between the urea and SCC levels, which was probably due to the wide variety of dairy producer profiles. The SCC values exhibited the largest amplitude variations. Most milk components significantly differed according to the strata, producer, food, and tank. These changes probably had little influence on the animal's physiology and productivity. Therefore, despite the small variations in the components of the milk supplied by ASRAW, the different types of milk storage tank, milk volume produced, and type of dairy producer affected the overall milk quality.
\end{abstract}

Key words: Association of dairy producers, milk composition, refrigerated raw milk

\section{Resumo}

Objetivou-se com o presente trabalho, avaliar a composição e qualidade do leite cru refrigerado,

\footnotetext{
${ }^{1}$ Discente de Mestrado do Programa de Pós-Graduação em Produção Animal, Universidade Federal Rural do Semiárido, UFERSA/ UFRN, Mossoró, RN, Brasil. E-mail: marconeangicano22@yahoo.com.br

2 Profs., Programa de Pós-graduação em Produção Animal, UFERSA/UFRN, Mossoró, RN, Brasil. E-mail: apbraga@ufersa.edu. br; ljmaroeira@yahoo.com.br

3 Prof., Programa de Pós-graduação em Produção Animal, Universidade Federal do Rio Grande do Norte, UFERSA/UFRN, Natal, RN, Brasil. E-mail: adrianohrangel@yahoo.com.br

${ }^{4}$ Discente de Doutorado, Programa de Doutorado Integrado em Zootecnia, Universidade Federal do Ceará, UFC/UFPB/UFRPE, Campus do Pici, Fortaleza, CE, Brasil. E-mail: mig_871@hotmail.com

* Author for correspondence
} 
proveniente de tanques, de acordo com o enquadramento dos produtores, o tipo de alimentação e os níveis de produção das propriedades que fornecem leite para a Associação dos Pequenos Agropecuaristas do Sertão de Angicos - APASA. Os dados coletados foram provenientes de 47 produtores, provenientes de diferentes cidades do estado do Rio Grande do Norte, vinculados a APASA. As coletas foram realizadas em 23 tanques ao longo do mês de junho de 2013, sendo duas coletas por semana, e cinco amostras por tanque, totalizando 920 observações. As propriedades foram caracterizadas de acordo com o tipo de tanque, particular ou comunitário; alimento fornecido durante as coletas, volumoso e volumoso + concentrado; o enquadramento do produtor, produtor familiar e não familiar; e por fim de acordo com a quantidade ou estrato de produção das propriedades. Foram realizadas as análises para os teores de gordura, proteína total, caseína, lactose, sólidos totais, extrato seco desengordurado (ESD), crioscopia, ureia, contagem de células somáticas (CCS) e resíduo de antibiótico. As análises estatísticas foram realizadas para cada grupo e as médias foram comparadas pelo Teste de Tukey, utilizando o nível de significância crítico de $5 \%$ de probabilidade através do procedimento PROC GLM do programa SAS ${ }^{\circledR}$. A maioria dos componentes diferiu estatisticamente para cada classe analisada. A ureia e a CCS foram os componentes que mantiveram as maiores diferenças e variações, provavelmente devido a grande variedade no perfil dos produtores, e também, no caso da CCS, na qual os valores observados sofreram grande variação de amplitude. A maioria dos componentes do leite apresentaram diferença estatística entre tipo de estrato, tipo de produtor, tipo de alimentação e tipo de tanque, mas a sua magnitude pode ser considerada de baixa importância e, provavelmente, pouco influencie na fisiologia e produtividade do animal. Portanto, concluiu-se que, apesar das pequenas variações encontradas nos componentes do leite fornecido a APASA, eles são influenciados pelos diferentes tipos de manejo alimentar, volume de leite produzido, bem como pelo tipo de produtor.

Palavras-chave: Associação de produtores, composição do leite, leite cru refrigerado

\section{Introduction}

Among the products that compose the human diet, milk is one of the most wholesome, as it contains essential elements for growth and health maintenance, such as proteins, fats, vitamins, and minerals. Because it is rich in nutrients, milk is susceptible to attack by a large number of microorganisms that are present in the environment, in the animal itself, in humans, and on the milking utensils (FRANCO et al., 2000; NICOLAU et al., 2004).

The term milk quality refers to not only the nutritional characteristics of the product but also the features of its production process, including milking hygiene and refrigeration and the maintenance of milk at temperatures of $4^{\circ} \mathrm{C}$, to ensure global food quality (RANGEL et al., 2009; GALVÃO JÚNIOR et al., 2010). Because of the various risks on public health caused by consuming raw milk, its use was banned in Brazil in 1952 (BRASIL, 1952). On September 18, 2002, Normative Instruction No. 51 was created
(BRASIL, 2002), which established standards for pasteurized milk.

In addition to the health aspects of milk, the desire for increased yields of dairy products has been guiding livestock genetic selections and the payment policies according to the quality, with a goal of milk with higher solid levels. Therefore, knowledge of the factors that influence the production, especially, the composition of milk, is crucial for the success of rural milk-producing enterprises (ARAÚJO, 2009).

A cooperative system, which establishes the criteria for receiving the milk to be subsequently transferred to the industry, is one way to standardize and organize the milk supply. In general, dairy producers in the Rio Grande do Norte are small and medium-sized, and the production of bovine milk was increased by the introduction of a milk program that aimed to fight malnutrition and child mortality by improving the partnership between associations, cooperatives, and the State Government (SOUSA JÚNIOR et al., 2009). 
Therefore, milk quality can be defined in terms of its integrity, including being free of added substances and/or component removal, its chemical composition and physical characteristics, and being free of microorganisms and pathogens. In this context, the physicochemical characteristics outside the standards set by the current legislation in Brazil can endanger consumer health, including addition of objectionable substances for consumption, which alter the milk composition (BRASIL, 2002).

Therefore, the aim of this study was to evaluate the quality of refrigerated raw milk by assessing the levels of milk components according to the dairy producers' structure, the type of food, and the production properties of the dairy producers that provide milk for the Association of Small-Scale Ranchers of the Angicos Wilderness (ASRAW).

\section{Material and Methods}

\section{Properties}

The cooled raw milk that was used for the analyses was collected from 47 producers who were associated with the ASRAW, which is located in Angicos city, Rio Grande do Norte. The criteria used in the selection of the properties that were used to perform the milk collection assessments were based on the access of the chosen dairy producers to private (16 tanks) or community (seven tanks) cooling tanks. These properties were characterized according to the type of tank (private or community) and the type of enterprise [family (15 dairy producers) or non-family (32 dairy producers)].

In addition, we examined the type of food that was supplied to the animals at the time of collection. Of the 23 tanks, four were used by the farmers to provide their animals only with voluminous food, which primarily consisted of forage from native grasslands (shrubs and trees) with low rainfall between April and May. The other dairy producers who supplied the remaining tanks provided the animals with voluminous and concentrated food. In this case, the provided forage was from the shrubs and tree shoots of native plants, and the concentrate was mainly composed of corn, soybeans, and cotton seed cakes. However, the proportion provided was not measured because most producers in this group did not balance the diet.

Finally, the levels of the amount of milk that was produced were divided into five production strata (L/day): up to 500 (stratum 1), 500-1000 (stratum 2), 1000-1500 (stratum 3), 1500-2000 (stratum 4), and over 2000 (stratum 5).

\section{Sample collection}

The samples were collected in 23 tanks in the farms that received bovine milk. These tanks received raw milk from 47 producers, including 20 from the municipality of Angicos, nine from Santana dos Matos, four from Fernando Pedroza, one from Ipanguaçu, nine from Pendência, three from Afonso Bezerra, and one from São Rafael, in the state of Rio Grande do Norte.

The collections were made twice a week (Monday and Wednesday) from June 1 to June 30, 2013. During the experiment, eight visits were made to each of the 23 milk-cooling tanks throughout the month. Five samples of raw milk were collected from each tank for a total of 920 samples. During these visits, we adopted the standards for the collection and shipment of milk that have been recommended by the Laboratory of Milk Quality, LABOLEITE of the Federal University of Rio Grande do Norte in Natal.

These collections were conducted after homogenization by mechanically stirring and then removing the sample from the tank that was at a temperature below $7^{\circ} \mathrm{C}$ with the aid of a properly sanitized stainless-steel soup-serving spoon. The milk samples were placed in 40-mL plastic bottles that were properly identified. Five measures were made in each tank. The samples were stored in individual coolers with ice, sealed with tape, and 
sent the same day of collection to LABOLEITE/ UFRN along with a spreadsheet identifying the properties and the number of the sample.

\section{Milk analysis}

The parameters that were analyzed were fat, total protein, casein levels, lactose levels, total solids, degreased dry extract (DDS), freezing point, urea levels, somatic cell count (SCC), and antibiotic residue.

For the analysis of the antibiotic residues, we used the Eclipse $50^{\circledR}$ kit, which consists of a qualitatively simple and rapid test that detects inhibitory substances and antibiotics at concentrations above the maximum residue limits based on the inhibition of microbial growth in milk. The kit was used according to the manufacturer's protocol (Cap Lab Indústria e Comércio Ltda).

For the SCC, a Somaticell ${ }^{\circledR}$ kit was used. The kit detects cells based on the property that milk somatic cells increase the viscosity of the product upon contact with a specific reagent. A positive correlation between the number of cells and milk viscosity was observed, so that the higher the viscosity the higher the amount of somatic cells. This qualitative test was adapted from the Wisconsin Mastitis Test that measures milk viscosity when added to a reagent by passing it through a calibrated orifice for a certain period (LANGONI, 2000).

Finally, to assess the levels of fat, total protein, casein, lactose, total solids, degreased dry extract (DDE), and urea and the freezing point, we used the DairySpec $\mathrm{FT}^{\circledR}$ milk analyzer, which captures the full infrared absorption spectrum for the analysis of its components.

\section{Data analysis}

The statistical analyses were performed with the PROC GLM procedure of $\mathrm{SAS}^{\circledR}$ software (version 9.1; SAS Institute, Inc., Cary, NC, USA).
Each milk component was analyzed to determine the effects of stratum production (L/day), which was divided into five levels, tank type (private or community), enterprise type (family or nonfamily), and diet (voluminous food and concentrate or only voluminous food). In all of the cases, we used analyses of variance, and the means were compared by Tukey tests. $\mathrm{P}$ values less than 0.05 were considered statistically significant.

\section{Results and Discussion}

The means and coefficients of variation that were obtained for each parameter in the samples collected from 23 tanks are shown in Table 1. These values were in agreement with the values reported in the literature for the components of refrigerated raw milk (GONZÁLEZ et al., 2004; LACERDA et al., 2010). SCC exhibited high variation between observations, and this was mainly due to the large variation in the profiles of the dairy producers, which varied according to the amount of milk produced and the type of food given to the animals. The analysis of antibiotic residue was negative for all of the samples.

Another component that showed a high coefficient of variation was urea, with an average of $22.47 \mathrm{mg} / \mathrm{mL}$, and this may have been because of the food used at the time, which was based largely on the regrowth of native plants that are rich in protein (Table 1). According to González et al. (2001) and Wang et al. (2007), increased levels of diet-metabolized protein induce a linear increase in urea concentration in blood plasma, urine, and milk.

The mean values of the different strata of physical and chemical production and SCC (Table 2) indicated a decrease in fat content as production increased, and a likely cause of this variation was the diluting effect of this constituent in milk. Thus, the higher the production (milk volume), the lower was the value for fat. 
Table 1. Descriptive analysis of the general structure data of physico-chemical components and SCC refrigerated raw milk produced by the properties linked to APASA.

\begin{tabular}{lccc}
\hline \multicolumn{1}{c}{ Components } & Mean & SD & CV (\%) \\
\hline Fat Content $(\% \mathrm{~m} / \mathrm{m})$ & 3.57 & 0.46 & 12.89 \\
Total Protein $(\% \mathrm{~m} / \mathrm{m})$ & 3.27 & 0.17 & 5.11 \\
Casein $(\% \mathrm{~m} / \mathrm{m})$ & 2.55 & 0.15 & 5.83 \\
Lactose $(\% \mathrm{~m} / \mathrm{m})$ & 4.78 & 0.14 & 2.96 \\
total solids $(\% \mathrm{~m} / \mathrm{m})$ & 12.48 & 0.60 & 4.82 \\
DDE $(\% \mathrm{~m} / \mathrm{m})$ & 8.89 & 0.28 & 3.10 \\
Freezing Point $\left({ }^{\circ} \mathrm{H}\right)$ & -0.549 & 0.0075 & - \\
Urea $(\mathrm{mg} / \mathrm{mL})$ & 22.47 & 3.87 & 17.21 \\
SCC $(\mathrm{mil} / \mathrm{mL})$ & 496.74 & 258.55 & 52.05 \\
\hline
\end{tabular}

SD: standard deviation, CV: coefficient of variation, DDE: degreased dry extract, SCC: somatic cell count.

Table 2. Values referring to the average for production's five strata / amount, and coefficient of variation (CV), for the components of caw's refrigerated raw milk produced by the properties linked to APASA.

\begin{tabular}{lcccccc}
\hline \multirow{2}{*}{ Components } & \multicolumn{5}{c}{ Production Strata (L/day) } & \multirow{2}{*}{ CV (\%) } \\
\cline { 2 - 5 } & $\begin{array}{c}\text { Stratum 1 } \\
(\text { até 500) }\end{array}$ & $\begin{array}{c}\text { Stratum 2 } \\
(500 \mathrm{a} 1000)\end{array}$ & $\begin{array}{c}\text { Stratum 3 } \\
(1000 \mathrm{a} \mathrm{1500)})\end{array}$ & $\begin{array}{c}\text { Stratum 4 } \\
(1500 \mathrm{a} 2000)\end{array}$ & $\begin{array}{c}\text { Stratum 5 } \\
(>2000)\end{array}$ & \\
\hline Fat Content $(\% \mathrm{~m} / \mathrm{m})$ & $3.66^{\mathrm{a}}$ & $3.75^{\mathrm{a}}$ & $3.29^{\mathrm{b}}$ & $3.12^{\mathrm{b}}$ & $3.17^{\mathrm{b}}$ & 11.50 \\
Total Protein $(\% \mathrm{~m} / \mathrm{m})$ & $3.31^{\mathrm{a}}$ & $3.34^{\mathrm{a}}$ & $3.24^{\mathrm{b}}$ & $3.13^{\mathrm{c}}$ & $3.00^{\mathrm{d}}$ & 4.32 \\
Casein $(\% \mathrm{~m} / \mathrm{m})$ & $2.58^{\mathrm{a}}$ & $2.60^{\mathrm{a}}$ & $2.47^{\mathrm{b}}$ & $2.43^{\mathrm{b}}$ & $2.33^{\mathrm{c}}$ & 5.02 \\
Lactose $(\% \mathrm{~m} / \mathrm{m})$ & $4.77^{\mathrm{b}}$ & $4.77^{\mathrm{b}}$ & $4.73^{\mathrm{b}}$ & $4.93^{\mathrm{a}}$ & $4.80^{\mathrm{b}}$ & 2.78 \\
total solids $(\% \mathrm{~m} / \mathrm{m})$ & $12.60^{\mathrm{a}}$ & $12.77^{\mathrm{a}}$ & $12.05^{\mathrm{b}}$ & $12.00^{\mathrm{cb}}$ & $11.78^{\mathrm{c}}$ & 4.27 \\
DDE $(\% \mathrm{~m} / \mathrm{m})$ & $8.91^{\mathrm{a}}$ & $8.96^{\mathrm{a}}$ & $8.74^{\mathrm{b}}$ & $8.88^{\mathrm{a}}$ & $8.60^{\mathrm{b}}$ & 2.97 \\
Freezing Point $\left({ }^{\circ} \mathrm{H}\right)$ & $-0.548^{\mathrm{a}}$ & $-0.555^{\mathrm{c}}$ & $-0.552^{\mathrm{bc}}$ & $-0.549^{\mathrm{ba}}$ & $-0.547^{\mathrm{a}}$ & - \\
Urea $(\mathrm{mg} / \mathrm{mL})$ & $21.69^{\mathrm{c}}$ & $21.13^{\mathrm{c}}$ & $24.65^{\mathrm{b}}$ & $26.48^{\mathrm{a}}$ & $24.09^{\mathrm{b}}$ & 15.83 \\
SCC $(\mathrm{mil} / \mathrm{mL})$ & $467.56^{\mathrm{cd}}$ & $373.60^{\mathrm{d}}$ & $1010.00^{\mathrm{a}}$ & $556.40^{\mathrm{cb}}$ & $662.00^{\mathrm{b}}$ & 46.78 \\
\hline
\end{tabular}

DDE: degreased dry extract, SCC: somatic cell counts.

Averages in the same row, followed by different letters which differ statistically $(\mathrm{P}<0.05)$ according to the Tukey test.

Other factors that may have influenced the fat content and the other components were the unbalanced diet with respect to forage, the concentration, genetic variations, age, and the physiological state of each animal group belonging to the respective strata. The composition of bovine milk changes according to different factors, such as herd, region, year, month, period of sample storage and somatic cell score, animal species, breed, milking period, and stage of lactation (SILVA, 1997; GONZÁLEZ et al., 2001; RIBAS et al., 2004; COSTA et al., 2009).
According to González et al. (2001), changes in protein occur between 0.1 and 0.2 percentage units, which are determined by genetics and, to a lesser extent, diet composition. However, Silva (1997) has reported a higher variation, which was around 0.4 percentage units. Peres (2001) suggested that a protein concentration around $3.5 \%$ is considered normal for milk.

The means of the parameters according to the different types of tanks are presented in Table 3. The levels of fat and total solids were not significantly different between the private and community tanks, 
while the levels of protein, casein, and urea were better in community tanks. These results were probably related to the diet of the animals, which, thus, produced higher concentrations of propionate. The high urea nitrogen concentration in the milk was probably caused by excess dietary protein.
Nutritional factors that cause increased levels of urea in milk are excess degradable nitrogen in the rumen, increased protein, which reaches the postruminal organs, and the lack of synchronization in the rumen degradation rates between the sources of nitrogen and energy (BAKER et al., 1995; BLOCK, 2000).

Table 3. Values referring to the average for the type of tank (private or community), and coefficients of variation (CV) for the components of raw milk refrigerated beef produced by the properties linked to APASA.

\begin{tabular}{lccc}
\hline \multirow{2}{*}{ Components } & \multicolumn{2}{c}{ Tank Type } & CV (\%) \\
\cline { 2 - 3 } & Private & Community & 12.89 \\
\hline Fat Content $(\% \mathrm{~m} / \mathrm{m})$ & $3.56^{\mathrm{a}}$ & $3.58^{\mathrm{a}}$ & 5.07 \\
Total Protein $(\% \mathrm{~m} / \mathrm{m})$ & $3.25^{\mathrm{b}}$ & $3.31^{\mathrm{a}}$ & 5.81 \\
Casein Levels $(\% \mathrm{~m} / \mathrm{m})$ & $2.54^{\mathrm{b}}$ & $2.57^{\mathrm{a}}$ & 2.85 \\
Lactose Levels $(\% \mathrm{~m} / \mathrm{m})$ & $4.80^{\mathrm{a}}$ & $4.71^{\mathrm{b}}$ & 4.82 \\
total solids $(\% \mathrm{~m} / \mathrm{m})$ & $12.49^{\mathrm{a}}$ & $12.44^{\mathrm{a}}$ & 3.08 \\
DDE $(\% \mathrm{~m} / \mathrm{m})$ & $8.90^{\mathrm{a}}$ & $8.83^{\mathrm{b}}$ & - \\
Freezing Point $\left({ }^{\circ} \mathrm{H}\right)$ & $-0.549^{\mathrm{b}}$ & $-0.547^{\mathrm{a}}$ & 17.11 \\
Urea Levels $(\mathrm{mg} / \mathrm{mL})$ & $22.70^{\mathrm{a}}$ & $21.64^{\mathrm{b}}$ & 50.15 \\
SCC $(\mathrm{mil} / \mathrm{mL})$ & $534.54^{\mathrm{a}}$ & $366.40^{\mathrm{b}}$ & \\
\hline
\end{tabular}

DDE: degreased dry extract, SCC: somatic cell counts.

Averages in the same row, followed by different letters which differ statistically $(\mathrm{P}<0.05)$ according to the Tukey test.

The average SCC varied according to tank type, with an average of 534.5 cells $/ \mathrm{mL}$ in private tanks, which was greater than the average of 366.4 cells $/ \mathrm{mL}$ in the community tanks (Table 3 ). This high private tank SCC count was probably because these tanks received milk from individual units and producers of greater volume, which is a disadvantage as the milk becomes diluted. However, the community tanks may have had the lowest average because of the influence of milk dilution, as they receive milk from various properties and in smaller volumes.

Understanding the dynamics of the SCC in the tanks is important for improving milk quality and herd management (MACHADO et al., 2000). Besides intramammary infections, other factors that may interfere with SCC are time of year, breed, stage of lactation, milk production, number of lactations, stress caused by deficiencies in management, nutritional problems, herd effect, climatic conditions, and concomitant diseases (MULLER, 2002).

The average values of the physicochemical composition of the milk according to the type of food are shown in Table 4. Significant differences were seen in all of the components, except DDE. The variations in total solid contents were largely dependent on the variations in milk fat content (PERES, 2001). Animals that were fed voluminous food had a higher percentage of total solids compared to those fed voluminous food + concentrate, and this was probably due to the highcarbohydrate diet. For urea content, animals fed voluminous and concentrate food had higher levels of urea $(22.72 \mathrm{mg} / \mathrm{mL})$. The higher the degradability of the dietary protein, the greater the production of ruminal ammonia, and, consequently, the higher concentrations of urea in serum and milk and the nitrogen losses in urine and milk (SANTOS et al., 
2001). A higher percentage of concentrate in the diet the ratio of acetate levels, such as propionate, which also influences $\mathrm{pH}$ values and, in particular, reduces decrease the milk fat content (COSTA et al., 2005).

Table 4. Amounts related to averages, according to the type of diet, whether it is either voluminous or voluminous + concentrate, and coefficients of variation (CV) for the components of raw milk refrigerated beef produced by the properties linked to APASA.

\begin{tabular}{lccc}
\hline \multirow{2}{*}{ Components } & \multicolumn{3}{c}{ Diet Type } \\
\cline { 2 - 4 } & Voluminous & Voluminous + Concentrated \\
\hline Fat Content $(\% \mathrm{~m} / \mathrm{m})$ & $3.95^{\mathrm{a}}$ & $3.50^{\mathrm{b}}$ & 12.03 \\
Total Protein $(\% \mathrm{~m} / \mathrm{m})$ & $3.31^{\mathrm{a}}$ & $3.26^{\mathrm{b}}$ & 5.09 \\
Casein Levels $(\% \mathrm{~m} / \mathrm{m})$ & $2.60^{\mathrm{a}}$ & $2.54^{\mathrm{b}}$ & 5.77 \\
Lactose Levels $(\% \mathrm{~m} / \mathrm{m})$ & $4.74^{\mathrm{b}}$ & $4.79^{\mathrm{a}}$ & 2.93 \\
total solids $(\% \mathrm{~m} / \mathrm{m})$ & $12.86^{\mathrm{a}}$ & $12.41^{\mathrm{b}}$ & 4.63 \\
DDE $(\% \mathrm{~m} / \mathrm{m})$ & $8.91^{\mathrm{a}}$ & $8.88^{\mathrm{a}}$ & 3.10 \\
Freezing Point $\left({ }^{\circ} \mathrm{H}\right)$ & $-0.550^{\mathrm{b}}$ & $-0.548^{\mathrm{a}}$ & - \\
Urea Levels $(\mathrm{mg} / \mathrm{mL})$ & $21.20^{\mathrm{b}}$ & $22.72^{\mathrm{a}}$ & 17.04 \\
SCC $(\mathrm{mil} / \mathrm{mL})$ & $442.93^{\mathrm{b}}$ & $507.66^{\mathrm{a}}$ & 51.88 \\
\hline
\end{tabular}

DDE: degreased dry extract, SCC: somatic cell counts.

Averages in the same row, followed by different letters which differ statistically $(\mathrm{P}<0.05)$ according to the Tukey test.

Protein and casein levels in the milk were affected by the type of food. Animals fed voluminous food had higher mean levels of these constituents, 3.31 $(\% \mathrm{~m} / \mathrm{m})$ and $2.60(\% \mathrm{~m} / \mathrm{m})$, respectively, compared to animals fed the other type of food. However, these data can probably be explained by the influence of animal genetics and not by the type of food itself.

Although lactose is one of the most stable nutrients in the chemical composition of milk (GONZÁLEZ et al., 2001; EGYPTO et al., 2007), lactose levels varied relative to voluminous food and voluminous and concentrate food diets: 4.74 and $4.79(\% \mathrm{w} / \mathrm{w})$, respectively (Table 4$)$. Lactose is the characteristic carbohydrate of milk, and it is synthesized from the glucose that is produced by the liver by propionic acid that is absorbed in the rumen and the transformation of some amino acids (GONZÁLEZ, 2007). However, as the concentration increases in the diet, rumen fermentation changes, resulting in increased production of propionic acid and high lactose content.
For very dry stratum, higher percentage of animals was fed voluminous food $(12.86 \% \mathrm{~m} / \mathrm{m}$; Table 4). This was probably due to the higher levels of fat, protein, and casein that were found in this experiment because the contents of the very dry stratum equaled the sum of all of the milk components, except water.

The mean and coefficient of variation data of the milk components according to the types of dairy producer are shown in Table 5. The results showed that, with the exception of fat and lactose, all of the milk components differed significantly $(\mathrm{p}<0.05)$. Family producers presented the best averages relative to the composition, and this was probably due to the large breed variations in this group as well as the food that these animals consumed, which was composed of voluminous and concentrate food. According to Ribas et al. (2004), the composition of bovine milk varies according to several factors, including herd and SSC content. 
Table 5. Values referring to the average, according to the type of enterprise, whether it is family or not family, and coefficients of variation (CV) for the components of raw milk refrigerated beef produced by the properties linked to APASA.

\begin{tabular}{lccc}
\hline \multirow{2}{*}{ Components } & \multicolumn{2}{c}{ Enterprise Type } & \multirow{2}{*}{ CV (\%) } \\
\cline { 2 - 3 } & Family & Nonfamily & 12.88 \\
\hline Fat Content $(\% \mathrm{~m} / \mathrm{m})$ & $3.64^{\mathrm{a}}$ & $3.56^{\mathrm{a}}$ & 5.06 \\
Total Protein $(\% \mathrm{~m} / \mathrm{m})$ & $3.34^{\mathrm{a}}$ & $3.26^{\mathrm{b}}$ & 5.79 \\
Casein Levels $(\% \mathrm{~m} / \mathrm{m})$ & $2.60^{\mathrm{a}}$ & $2.54^{\mathrm{b}}$ & 2.96 \\
Lactose Levels $(\% \mathrm{~m} / \mathrm{m})$ & $4.77^{\mathrm{a}}$ & $4.79^{\mathrm{a}}$ & 4.79 \\
total solids $(\% \mathrm{~m} / \mathrm{m})$ & $12.68^{\mathrm{a}}$ & $12.45^{\mathrm{b}}$ & 3.09 \\
DDE $(\% \mathrm{~m} / \mathrm{m})$ & $8.94^{\mathrm{a}}$ & $8.88^{\mathrm{a}}$ & - \\
Freezing Point $\left({ }^{\circ} \mathrm{H}\right)$ & $-0.551^{\mathrm{b}}$ & $-0.548^{\mathrm{a}}$ & 17.02 \\
Urea Levels $(\mathrm{mg} / \mathrm{mL})$ & $24.17^{\mathrm{a}}$ & $22.27^{\mathrm{b}}$ & 49.57 \\
SCC $(\mathrm{mil} / \mathrm{mL})$ & $273.00^{\mathrm{b}}$ & $525.08^{\mathrm{a}}$ & \\
\hline
\end{tabular}

DDE: degreased dry extract, SCC: somatic cell count.

Averages in the same row, followed by different letters which differ statistically $(\mathrm{P}<0.05)$ according to the Tukey test.

Urea levels were significantly different with an average of about $24.17 \mathrm{mg} / \mathrm{mL}$ (Table 5). This might have occurred due to diet imbalance, which resulted in changes in the rumen, in turn causing increased concentration of this component in milk. According to Gaona (2002), the normal levels of urea in milk are between 10 and $16 \mathrm{mg} / \mathrm{dL}$. Torrent (2000) reported that the amounts of urea in the milk of cows with high intake of dry matter typically fall in the range of $12-18 \mathrm{mg} / \mathrm{dL}$.

The SCC index was lower for family dairy producers, which might have been due to the decreased production of these animals and, consequently, lower mammary gland demand. This value may also be associated with the volume produced because family farmers also supply community tanks, which have less milk per dairy producer and lower SCC content.

\section{Conclusion}

The results of this study indicated that dietary practice, the volume of milk produced, and the type of dairy producer influenced milk composition. Most milk components differed marginally according to the type of stratum, type of producer, type of food, and type of tank. Thus, obvious gains or losses of most of the components were not noted among the different treatments.

Despite the small changes found, the milk supplied by ASRAW is within the standards and requirements of the Brazilian norms of milk quality.

\section{Acknowledgments}

We are grateful to the Association of SmallScaled Ranchers of Angicos Wilderness (ASRAW) for supplying the milk samples for the analysis.

\section{References}

ARAÚJO, V. M. Monitoramento da qualidade do leite. In: BRITO, A. C.; NOBRE, F. V.; FONSECA, J. R. R. (Org.). Bovinocultura leiteira: informações técnicas e de gestão. Natal: SEBRAE/RN, 2009. p. 239-246.

BAKER, L. D.; FERGUSON, J. D.; CHALUPA, W. Reponses in urea and true protein of milk to different protein feeding schemes for dairy cows. Journal of Dairy Science, Madison, v. 78, n. 11, p. 2424-2434, 1995.

BLOCK, E. Nutrição de vacas leiteiras e composição do leite. In: SIMPÓSIO INTERNACIONAL SOBRE QUALIDADE DO LEITE, 2., 2000. Curitiba. Anais... Curitiba: Associação Paranaense de Criadores de 
Bovinos da Raça Holandesa/Universidade Federal do Paraná, 2000. p. 85-88.

BRASIL. Instrução Normativa $\mathrm{n}^{\circ}$ 51, de 20 de setembro de 2002. Aprova regulamentos técnicos de produção, identidade e qualidade do leite cru refrigerado. Diário Oficial [da] União, Brasília, 21 set. 2002. Seção I, p. 13.

Ministério da Agricultura, do Abastecimento e da Reforma Agrária. Departamento Nacional de Inspeção de Produtos de Origem Animal. Regulamento de Inspeção Indústria e Sanitária de Produtos de Origem Animal. Diário Oficial [da] União, Brasília, aprovado pelo Decreto 30. 691 de 29 de março de 1952 e alterado pelo Decreto 1. 255 de 25 jun. 1962. Rio de Janeiro, 1952.

COSTA, M. G.; CAMPOS, J. M. D. S.; VALADARES FILHO, S. D. C.; VALADARES, R. F. D.; MENDONÇA, S. D. S.; SOUZA, D. D. P.; TEIXEIRA, M. D. P. Desempenho produtivo de vacas leiteiras alimentadas com diferentes proporções de cana-de-açúcar e concentrado ou silagem de milho na dieta. Revista Brasileira de Zootecnia, Viçosa, MG, v. 34, n. 6, p. 2437 2445, 2005.

COSTA, R. G.; QUEIROGA, R. C. R.; PEREIRA, R. A. G. Influência do alimento na produção e qualidade do leite de cabra. Revista Brasileira de Zootecnia, Viçosa, MG, v. 38, p. 307-321, 2009. Suplemento Especial.

SOUSA JÚNIOR, S. C. de; MORAIS, D. A. E. F.; FARIA, R. A. de; OLIVEIRA, S. M. P. de; SANTOS, D. O.; OLIVEIRA NETO, P. C. de. Análise econômica da produção anual de leite bovino em uma fazenda comercial no município de Baraúna, RN. Acta Veterinaria Brasilica, Mossoró, v. 2, n. 4, p. 131-139, 2009.

EGYPTO, R.D.C.R.; QUEIROGA, R. G.C.; BARRETO, T. M.; BISCONTINI, A. N. D. M.; MADRUGA, M. S.; RICARDO, A.; SCHULER, P. Influência do manejo do rebanho, das condições higiênicas da ordenha e da fase de lactação na composição química do leite de cabras Saanen. Revista Brasileira de Zootecnia, Viçosa, MG, v. 36, n. 2, p. 430-437, 2007.

FRANCO, R. M.; CAVALCANTI, R. M. S.; WOOD, P. C. B.; LORETTI, V. P.; GONÇALVES, P. M. R.; OLIVEIRA, L. A. T. Avaliação da qualidade higiênicosanitária de leite e derivados. Revista Higiene Alimentar, São Paulo, v. 14, n. 68, p. 70-77, 2000.

GALVÃO JÚNIOR, J. G. B.; RANGEL, A. H. N.; MEDEIROS, H. R.; SILVA, J. B. A.; AGUIAR, E. M.; MADRUGA, R. C.; LIMA JÚNIOR, D. M. Efeito da produção diária e da ordem de parto na composição físico-química do leite de vacas de raças zebuínas. Acta Veterinaria Brasilica, Mossoró, v. 4, n. 1, p. 25-30, 2010.
GAONA, R. C. Alguns indicadores metabólicos no leite para avaliar a relação nutrição: fertilidade. In: CONGRESSO NACIONAL DE MEDICINA VETERINÁRIA. GRAMADO, 29., 2002, Gramado. Anais... Gramado: Conbravet, 2002. p. 40-48.

GONZÁLEZ, F. H. D. Pode o leite refletir o metabolismo da vaca? In: DÜRR, J. W.; CARVALHO, M. P. de; SANTOS, M. V dos. (Ed.). O compromisso com a qualidade do leite no Brasil. Passo Fundo: UPF Editora, 2004. p. 195-209.

GONZÁLEZ, F. H. D.; DÜRR, J. W.; FONTANELI, R. S. Uso do leite para monitorar a nutrição e o metabolismo de vacas leiteiras. Porto Alegre: Gráfica UFRGS, 2001. $77 \mathrm{p}$.

GONZÁlEZ, H. L. Produção e qualidade do leite de vacas Jersey em pastagem cultivada anual de inverno com e sem suplementação. 2007. Tese (Doutorado em Zootecnia) - Universidade Federal de Pelotas, Porto Alegre.

LACERDA, L. M.; MOTA, R. A.; SENA, M. J. Contagem de células somáticas, composição e contagem bacteriana total do leite de propriedades leiteiras nos 75 municípios de Miranda do Norte, Itapecurú-Mirim e Santa Rita, Maranhão. Arquivo do Instituto Biológico, São Paulo, v. 77, n. 2, p. 209-215, 2010.

LANGONI, H. Tendências de modernização do setor lácteo: monitoramento da qualidade do leite pela contagem de células somáticas. Revista de Educação Continuada do CRMV-SP, São Paulo, v. 3, n. 3, p. 57-64, 2000.

MACHADO, P. F.; PEREIRA, A. R.; SARRIES, G. A. Composição do leite de tanques de rebanhos brasileiros distribuídos segundo sua contagem de células somáticas. Revista Brasileira de Zootecnia, Viçosa, MG, v. 29, n. 6, p. 1883-1886, 2000.

MULLER, E. E. Qualidade do leite, células somáticas e prevenção da mastite. In: SUL-LEITE, SIMPÓSIO SOBRE SUSTENTABILIDADE DA PECUÁRIA LEITEIRA NA REGIÃO SUL DO BRASIL, 2., Toledo. Anais... Toledo: [s.n.], 2002. p. 206-217.

NICOLAU, E. S.; MESQUITA, A. J.; BORGES, G. T.; KUAYE, A. Y. Staphylococcus aureus no processamento de queijo mussarela: detecção e avaliação da provável origem das linhagens isoladas. Revista Higiene Alimentar, São Paulo, v. 18, n. 125, p. 51-56, 2004.

PERES, J. R. O leite como ferramenta no monitoramento nutricional. In: GONZÁLEZ, F. H. D. (Ed.). Uso do leite para monitorar a nutrição e o metabolismo de vacas leiteiras. Porto Alegre: gráfica da UFRGS, 2001. p. 3045. 
RANGEL, A. H. N.; MEDEIROS, H. R.; SILVA, J. B.; BARRETO, M. L. D. J.; LIMA JÚNIOR, D. M. Correlação entre a contagem de células somáticas (CCS) e o teor de gordura, proteína, lactose e extrato seco desengordurado do leite. Revista Verde de Agroecologia e Desenvolvimento Sustentável, Pombal, v. 4, n. 3, p. 5760, 2009.

RIBAS, N. P.; HORTMANN, W.; MONARDES, H. G.; ANDRADE, U. D. Sólidos totais do leite em amostras de tanques nos Estados do Paraná, Santa Catarina e São Paulo. Revista Brasileira de Zootecnia, Viçosa, MG, v. 33, n. 6, p. 2343-2350, 2004.

SANTOS, G. T.; CAVALIERI, F. L. B.; MODESTO, E. C. Recentes avanços em nitrogênio não proteico na nutrição vacas leiteiras. In: SINLEITE - NOVOS CONCEITOS EM NUTRIÇÃO, 2., 2001, Lavras. Anais... Lavras: Universidade Federal de Lavras, 2001. p. 225-248.
SILVA, P. H. F. Leite: aspectos de composição e propriedades. Redes, Juiz de Fora, v. 1, n. 6, p. 3-5, 1997.

TORRENT, J. Nitrogênio uréico no leite e qualidade do leite. In: SIMPÓSIO INTERNACIONAL SOBRE QUALIDADE DO LEITE, 2., 2000, Curitiba. Anais... Curitiba: Associação Paranaense de Criadores de Bovinos da Raça Holandesa/Universidade Federal do Paraná, 2000. p. 27-29.

WANG, C.; LIU, J. X.; YUAN, Z. P.; WU, Y. M.; ZHAI, S. W.; YE, H. W. Effect of level of metabolizable protein on milk production and nitrogen utilization in lactating dairy cows. Journal of Dairy Science, Madison, v. 90, n. 6, p. 2960-2965, 2007. 